\section{(6) OPEN ACCESS}

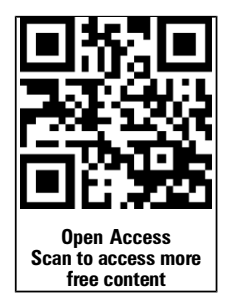

- Additional material is published online only. To view please visit the journal online (http://dx.doi.org/10.1136/ jmedgenet-2015-103302)

For numbered affiliations see end of article.

Correspondence to Professor Agnès Bloch-Zupan, Faculty of Dentistry, University of Strasbourg, 8 rue St Elisabeth Strasbourg 67000, France; agnes.bloch-zupan@unistra.fr

Received 6 June 2015 Revised 8 September 2015 Accepted 24 September 2015 Published Online First 26 October 2015

\section{CrossMark}

\section{To cite: Prasad MK,} Geoffroy V, Vicaire $S$, et al. J Med Genet 2016;53: 98-110.

\title{
A targeted next-generation sequencing assay for the molecular diagnosis of genetic disorders with orodental involvement
}

Megana K Prasad, ${ }^{1}$ Véronique Geoffroy, ${ }_{1}^{1}$ Serge Vicaire, ${ }^{2}$ Bernard Jost, ${ }^{2}$ Michael Dumas, ${ }^{2}$ Stéphanie Le Gras, ${ }^{2}$ Marzena Switala, ${ }^{3,4}$ Barbara Gasse, ${ }^{5}$ Virginie Laugel-Haushalter, ${ }^{6}$ Marie Paschaki, ${ }^{1,6}$ Bruno Leheup, ${ }^{7}$ Dominique Droz, ${ }^{8}$ Amelie Dalstein, ${ }^{8}$ Adeline Loing, ${ }^{3}$ Bruno Grollemund, ${ }^{4}$ Michèle Muller-Bolla, ${ }^{9,10}$ Séréna Lopez-Cazaux, ${ }^{11}$ Maryline Minoux, ${ }^{3,4}$ Sophie Jung, ${ }^{3,4}$ Frédéric Obry, ${ }^{3,4}$ Vincent Vogt ${ }^{3,4}$ Jean-Luc Davideau, ${ }^{4}$ Tiphaine Davit-Beal, ${ }^{5,12}$ Anne-Sophie Kaiser, ${ }^{13}$ Ute Moog ${ }_{1}^{13}$ Béatrice Richard, ${ }^{14}$ Jean-Jacques Morrier, ${ }^{14}$ Jean-Pierre Duprez, ${ }^{14}$ Sylvie Odent, ${ }^{15}$ Isabelle Bailleul-Forestier ${ }^{16}$ Monique Marie Rousset, ${ }_{1}^{17}$ Laure Merametdijan, ${ }^{18}$ Annick Toutain, ${ }^{19}$ Clara Joseph, ${ }^{20}$ Fabienne Giuliano, ${ }^{21}$ Jean-Christophe Dahlet, ${ }^{3}$ Aymeric Courval, ${ }^{22}$ Mustapha El Alloussi, ${ }^{23}$ Samir Laouina, ${ }^{23}$ Sylvie Soskin, ${ }^{24}$ Nathalie Guffon, ${ }^{25}$ Anne Dieux, ${ }^{26}$ Bérénice Doray, ${ }^{27}$ Stephanie Feierabend, ${ }^{28}$ Emmanuelle Ginglinger, ${ }^{29}$ Benjamin Fournier, ${ }^{30,31}$ Muriel de la Dure Molla, ${ }^{30,31}$ Yves Alembik, ${ }^{27}$ Corinne Tardieu, ${ }_{1}^{32}$ François Clauss, ${ }^{3,4}$ Ariane Berdal, ${ }_{1}^{30,31}$ Corinne Stoetzel, ${ }_{1}^{1}$ Marie Cécile Manière, ${ }^{3,4}$ Hélène Dollfus, ${ }^{1,33}$ Agnès Bloch-Zupan ${ }^{3,4,6}$

\section{ABSTRACT}

Background Orodental diseases include several clinically and genetically heterogeneous disorders that can present in isolation or as part of a genetic syndrome. Due to the vast number of genes implicated in these disorders, establishing a molecular diagnosis can be challenging. We aimed to develop a targeted next-generation sequencing (NGS) assay to diagnose mutations and potentially identify novel genes mutated in this group of disorders.

Methods We designed an NGS gene panel that targets 585 known and candidate genes in orodental disease. We screened a cohort of 101 unrelated patients without a molecular diagnosis referred to the Reference Centre for Oro-Dental Manifestations of Rare Diseases, Strasbourg, France, for a variety of orodental disorders including isolated and syndromic amelogenesis imperfecta (AI), isolated and syndromic selective tooth agenesis (STHAG), isolated and syndromic dentinogenesis imperfecta, isolated dentin dysplasia, otodental dysplasia and primary failure of tooth eruption.

Results We discovered 21 novel pathogenic variants and identified the causative mutation in 39 unrelated patients in known genes (overall diagnostic rate: 39\%). Among the largest subcohorts of patients with isolated Al (50 unrelated patients) and isolated STHAG (21 unrelated patients), we had a definitive diagnosis in 14 $(27 \%)$ and 15 cases $(71 \%)$, respectively. Surprisingly, COL17A1 mutations accounted for the majority of autosomal-dominant $\mathrm{Al}$ cases.

Conclusions We have developed a novel targeted NGS assay for the efficient molecular diagnosis of a wide variety of orodental diseases. Furthermore, our panel will contribute to better understanding the contribution of these genes to orodental disease.

Trial registration numbers NCT01746121 and NCT02397824.

\section{INTRODUCTION}

Orodental disorders encompass a number and variety of diseases that affect the teeth and oral cavity. Broadly, these disorders can be classified into anomalies of tooth number, shape and size (eg, hypo/oligo/ano-dontia (collectively selective tooth agenesis (STHAG)), microdontia, globodontia), anomalies of tooth structure (eg, amelogenesis imperfecta (AI), hereditary dentin disorders) and anomalies of tooth eruption. The prevalence of these disorders varies from relatively common (4.2\% for hypodontia in the Caucasian population $)^{1}$ to extremely rare (1 in 100000 for dentin dysplasia (DD) type 1$)^{2}$

Orodental disorders can have a genetic, environmental or multifactorial basis. ${ }^{3} 4$ Although evidence demonstrates a role for environmental pollutants such as dioxins and fluoride in developmental enamel defects, ${ }^{5} 6$ a number of studies have also demonstrated a strong genetic aetiology for several orodental diseases (reviewed in refs. 7-9). Among the $>5000$ known genetic syndromes, $>900$ have orodental/craniofacial features. ${ }^{10}$ Even in the case of isolated orodental diseases, significant genetic heterogeneity exists, with several of the same genes being involved in isolated and syndromic forms of 
disease. For instance, mutations in eight genes have been implicated in STHAG (PAX9, MSX1, LTBP3, AXIN2, WNT10A, EDA, EDARADD and EDAR), ${ }^{11-17}$ of which several (MSX1, WNT10A, $E D A, E D A R A D D$ and $E D A R$ ) have also been linked with forms of ectodermal dysplasia. ${ }^{18-20}$ Similarly, mutations in a number of genes have been implicated thus far in AI, of which 10 cause an exclusively dental phenotype (ENAM, WDR72, KLK4, AMELX, MMP20, FAM83H, AMBN, ITGB6, SLC24A4 and c4orf 26), ${ }^{21-30}$ some cause syndromic disease with AI (LTBP3, FAM20A, CNNM4, ROGDI, STIM1 and FAM20C), ${ }^{31-36}$ and yet others account for isolated and syndromic AI (COL17A1, $L A M A 3, L A M B 3$ and DLX3). ${ }^{37-40}$ Indeed, the pattern of inheritance and penetrance associated with each gene also varies. This wide range of heterogeneity can render genetic diagnosis challenging.

Yet, the early molecular diagnosis of orodental disorders is important as it can improve patient care. For instance, mutations in AXIN2 that cause STHAG have been shown to predispose carriers to colorectal cancer. ${ }^{12}$ Early diagnosis of AXIN2 mutations can hence alert clinicians to counsel patients to have regular colonoscopies. Similarly, the identification of mutations in FAM20A in patients presenting with AI can prompt a renal investigation for the management of nephrocalcinosis. ${ }^{41}$

Targeted next-generation sequencing (NGS) has proven extremely beneficial clinically for the molecular diagnosis of a number of genetically heterogeneous disorders, such as hearing loss, mitochondrial disease, intellectual disability (ID), neuromuscular disorders and Bardet-Biedl syndrome. ${ }^{42-46}$ Better coverage, lower cost and relative ease of data interpretation have made it more commonplace for routine clinical use than wholeexome sequencing (WES) and whole-genome sequencing (WGS). ${ }^{47}$

We have developed the first targeted NGS panel for the molecular diagnosis of isolated and syndromic orodental disorders. We demonstrate the utility of this panel in the molecular diagnosis of a variety of orodental disorders. In a cohort of 103 patients (101 unrelated) without a known molecular diagnosis referred to the Reference Centre for Rare Diseases with Oro-dental Manifestations, we were able to provide a definitive molecular diagnosis in 39\% of patients in known disease-causing genes. The identification of mutations in genes underlying syndromic forms of orodental disease highlights the potential benefits of a complete oral investigation in the diagnosis of rare genetic diseases. The aim of this article is to demonstrate the utility of this targeted NGS assay for the diagnosis of mutations in known orodental disease genes. However, the potential for the discovery of novel genes is addressed in the discussion.

\section{METHODS}

Patients

Patients were referred to the Reference Centre for Rare Diseases with Oro-dental Manifestations (Strasbourg, France) by dentists, paediatricians and geneticists from 13 hospitals and 32 private practices in France, Germany and Morocco. The inclusion criterion for the study was the presence of an orodental anomaly, defined as an anomaly of the mouth, including teeth and surrounding structures such as the periodontium (alveolar bone, ligament and gingivae), as well as defects of lip and palate formation. Patients with known mutations used for the validation assay were previously diagnosed either in clinical (Laboratory for Genetic Diagnosis, Strasbourg University Hospital) or research laboratories. DNA was obtained from peripheral blood or saliva samples (Oragene DNA, DNA Genotek, Canada).
Patient phenotype was recorded using D[4]/Phenodent (http:// www.phenodent.org).

\section{Gene selection and targeted capture design}

Genes were selected based on their involvement in human diseases with orodental phenotypes, mutation in animal models presenting orodental disorders, ${ }^{48} 49$ expression in the developing mouse tooth ${ }^{50}$ and known role in tooth development. Two versions of the gene panel were developed, v1.0 and v2.0. v1.0 was used for patients V1.01-V1.16, whereas v2.0 was used for patients V2.01-V2.95. Complementary RNA capture probes were designed against all coding exons and $25 \mathrm{bp}$ of flanking intronic sequence in order to cover splice junctions of these genes using the SureDesign portal (https://erray.chem.agilent. com/suredesign, Agilent, USA).

\section{Library preparation, sequencing and data analysis}

Targeted regions were captured using a Custom SureSelectXT2 in-solution target enrichment kit (Agilent) and libraries were prepared for sequencing $(2 \times 100 \mathrm{bp})$ on the HiSeq2500 (Illumina, USA) following the manufacturer's instructions. For v1.0, 16 samples were multiplexed per lane for sequencing, whereas for v2.0, 32 samples were multiplexed per flow-cell lane. Read alignment, and variant calling and annotation were performed using standard methods. Briefly, reads were aligned to the GRCh37 reference genome using Burrow-Wheeler aligner (v0.7.5a) ${ }^{51}$ ensuring tagging of multi-mapped reads, and duplicates were marked with Picardv1.102 (http://picard. sourceforge.net). Indel realignment, base quality score recalibration and variant calling were performed with the GATK Toolkit v3.1 using hard-filtering parameters. ${ }^{52-54}$ Variants were annotated using snpEffv.3.4. ${ }^{55}$ Variant frequencies were compared with an internal exome database and prioritised using VARank. ${ }^{56}$ Variants were prioritised by allele frequency $(<1 \%$ in the Single Nucleotide Polymorphism database (dbSNP137), 1000 Genomes database, ${ }^{57}$ Exome Variant Server (EVS) database $^{58}$ and our internal database, except for non-syndromic STHAG, for which we used a cut-off of $<4 \%$ ) and predicted functional effect (frameshift, invariant splice sites, nonsynonymous and splice affecting mutations). Missense mutations were evaluated for pathogenicity bioinformatically using Sorting Intolerant from Tolerant (SIFT), PolyPhen, MutationTaster and amino acid conservation. ${ }^{59-61}$ Splice affecting mutations were evaluated bioinformatically using Human Splice Finder, MaxEntScan, NNSplice, Gene Splicer, SSF, Rescue ESE and ESE Finder. $^{62-67}$ CNVs were detected as previously described. ${ }^{44} 45$ Variant pathogenicity was interpreted according to the American College of Medical Genetics guidelines. ${ }^{68}$ Evidence used to establish pathogenicity is provided in online supplementary figures S1-S45.

\section{Mutation validation}

All mutations were validated by Sanger sequencing (GATC, Germany). Segregation analyses were performed whenever DNA was available for additional family members. Single-molecule PCR followed by Sanger sequencing was used to phase biallelic mutations when parental DNA was unavailable. ${ }^{69} 70$ Deletions were validated by qPCR. The region of interest and an internal control region (RPPH1) were amplified from $2 \mathrm{ng}$ of genomic DNA from the patient and a control using the iQ SYBR Green Supermix (170-8880, Biorad, USA) on a CFX96 Real-Time System (Biorad). Data were analysed using the Pfaffl method. ${ }^{71}$ 


\section{RESULTS}

\section{Validation of $\mathbf{v} 1.0$ of the NGS panel}

As a proof of principle, we created a primary version (v1.0) of a custom NGS panel that targets 560 known and candidate genes $(2.36 \mathrm{Mb})$ in orodental disorders. Of these genes, probes for 175 known and strong candidate genes $(0.81 \mathrm{Mb})$ were designed to have superior coverage (diagnosis subpanel), whereas the remaining candidate genes constituted a 'Discovery subpanel' (see online supplementary tables S1 and S2). We validated v1.0 in a cohort of 16 patients: patients V1.01-V1.08 with isolated and/or syndromic orodental diseases with known mutations as determined by previous candidate gene Sanger sequencing, WES, or array CGH (see online supplementary table S3) and patients V1.09-V1.16 without a known molecular diagnosis. Patients V1.01-V1.08 were selected to include a variety of heterozygous, homozygous and hemizygous mutations (substitutions, indels, a large heterozygous deletion) at eight different loci in order to test the sensitivity of the gene panel to different types of genetic alterations. Using our computational pipeline, 10 of 10 mutations, including a large heterozygous deletion on the $\mathrm{X}$ chromosome (see online supplementary table S3), were detected in a blinded manner by a bioinformatician who was unaware of the molecular alteration but was aware of the clinical diagnosis for each patient. The bioinformatician was also blinded to the mode of inheritance in order to simulate a diagnostic scenario where such information is often unavailable. Samples V1.09-V1.16 were selected to cover a variety of orodental phenotypes (AI, dentinogenesis imperfecta (DGI), DD, STHAG) to determine the potential to identify unknown mutations with our panel. The molecular results from samples V1.09-V1.16 are presented and discussed in tables 1-3, together with the results from v2.0 of the gene panel presented below. Briefly, pathogenic or likely pathogenic mutations were identified in six of eight samples among samples V1.09-V1.16 (tables 2 and 3).

On average, in this validation cohort, by multiplexing 16 samples per lane of a sequencing flow cell, $2.2 \mathrm{~Gb}$ of sequence was generated per sample, giving a mean coverage of $365 \times$, with $95.31 \%$ nucleotides covered at $\geq 50 \times$ (see online supplementary table $\mathrm{S} 4$ ). The mean coverage of the diagnostic subpanel was $404 \times$, with $98.94 \%$ of nucleotides covered at $\geq 20 \times$, permitting confident diagnosis of mutations in these genes, for which we set a minimum coverage threshold of $20 \times$ (see online supplementary table S4). A small percentage of targeted regions $(33.3 \mathrm{~kb}, 1.4 \%)$ had an average coverage $<20 \times$ across samples due to high guanine-cytosine (GC) content or pseudogenes with highly similar sequences (see online supplementary table S5). The majority of these regions were in the discovery subpanel $(28.1 \mathrm{~kb})$. Under-representation of high GC content and pseudogenic regions is a known issue with probe-based targeting strategies. However, these gaps can be filled in by Sanger sequencing for regions considered to be relevant on a case-by-case basis. On average, we detected $\sim 2648$ variants/ sample, of which $\sim 87$ variants/sample were rare $(<1 \%$ in dbSNP137, 1000Genomes, EVS and an in-house database). Among these rare variants, we identified on average per sample $\sim 20$ missense changes, 0.38 nonsense mutations, 0.25 splice-site changes and 0.56 frameshift-inducing indels (see online supplementary table S6).

\section{Development of v2.0 of the NGS panel}

Having validated v1.0 of our NGS gene panel, we included 25 additional genes to the discovery subpanel to create a second version of the panel (v2.0) that included 585 genes $(2.47 \mathrm{Mb})$. These additional genes were included due to their implication in animal models of orodental disease that was unknown when designing v1.0 of the panel v2.0 of the panel was used to sequence 95 patients (V2.01-V2.95). Furthermore, since the average coverage achieved with $\mathrm{v} 1.0$ was more than sufficient for confident molecular diagnosis, with v2.0, 32 samples were multiplexed per well of a flow cell lane in order to reduce sequencing costs while ensuring a minimum average coverage of $100 \times$ per sample. Sequencing output with v2.0 is shown in online supplementary table S7. Briefly, we achieved a mean coverage of $179 \times$ overall, with $97.2 \%$ of the targeted region covered at $\geq 20 \times$. Furthermore, the diagnostic panel had an average coverage of $211 \times$ with $97 \%$ of bases covered at $\geq 50 \times$.

\section{Screening a cohort of patients with diseases with orodental involvement}

A description of the final cohort of 103 patients (101 unrelated) without a known mutation sequenced with v1.0 (V1.09-V1.16) and v2.0 (V2.01-2.95) and the diagnostic yield by disease category is shown in table 1 . Isolated AI was the most common disorder in the cohort $(50 \%)$, followed by isolated STHAG $(20 \%)$. We also included several patients with syndromic forms of AI, ranging from well-defined syndromes, such as Enamel Renal Syndrome, to undefined and suspected syndromes, hoping that a molecular diagnosis may aid difficult clinical diagnosis. The remaining cases consisted of patients with isolated or syndromic dentin disorders, syndromic STHAG, suspected otodental dysplasia and primary failure of tooth eruption. Since AI and STHAG can be inherited in an autosomal-dominant (AD),

\begin{tabular}{lll}
$\begin{array}{l}\text { Table } 1 \\
\text { category }\end{array}$ & $\begin{array}{l}\text { Number of } \\
\text { patients }\end{array}$ & $\begin{array}{l}\text { Diagnostic } \\
\text { yield, N (\%) }\end{array}$ \\
\hline Disease & $52\left(51^{*}\right)$ & $14(27 \%)$ \\
\hline Isolated Al & $51\left(50^{*}\right)$ & $15\left(29 \%, 30 \%{ }^{*}\right)$ \\
Of which confirmed Al & 1 & $0(0 \%)$ \\
Of which suspected AI & 14 & $1(7 \%)$ \\
Syndromic Al & 1 & $1(100 \%)$ \\
Enamel renal syndrome & 1 & $0(0 \%) \dagger$ \\
Mucopolysaccharidosis IV A & 1 & $0(0 \%)$ \\
Kohlschutter Tonz (suspected) & 1 & $0(0 \%)$ \\
Osteogenesis imperfecta (suspected) & 1 & $0(0 \%) \dagger$ \\
Spondyloepiphyseal dysplasia & 9 & $0(0 \%)$ \\
Undefined syndrome & 21 & $15(71 \%)$ \\
Isolated STHAG & 4 & $2(50 \%)$ \\
Syndromic STHAG & 3 & $1(33 \%)$ \\
Ectodermal dysplasia & 1 & $1(100 \%)$ \\
Intellectual disability with STHAG & $5\left(4^{*}\right)$ & $5,4^{*}(100 \%)$ \\
Isolated DGI & 2 & $1(50 \%)$ \\
Syndromic DGI & 1 & $0(0 \%)$ \\
Goldblatt syndrome (suspected) & 1 & $1(100 \%)$ \\
Osteogenesis imperfecta & 2 & $1(50 \%)$ \\
Isolated DD & 1 & $1(100 \%)$ \\
Otodental syndrome & 2 & $0(0 \%)$ \\
Primary failure of tooth eruption & $103\left(101^{*}\right)$ & $40,39^{*}(39 \%)$ \\
Total & &
\end{tabular}

*Number of unrelated patients.

tLikely pathogenic mutations were identified in GALNS in these patients.

$\mathrm{Al}$, amelogenesis imperfecta; $\mathrm{DD}$, dentin dysplasia; $\mathrm{DGI}$, dentinogenesis imperfecta; STHAG, selective tooth agenesis. 


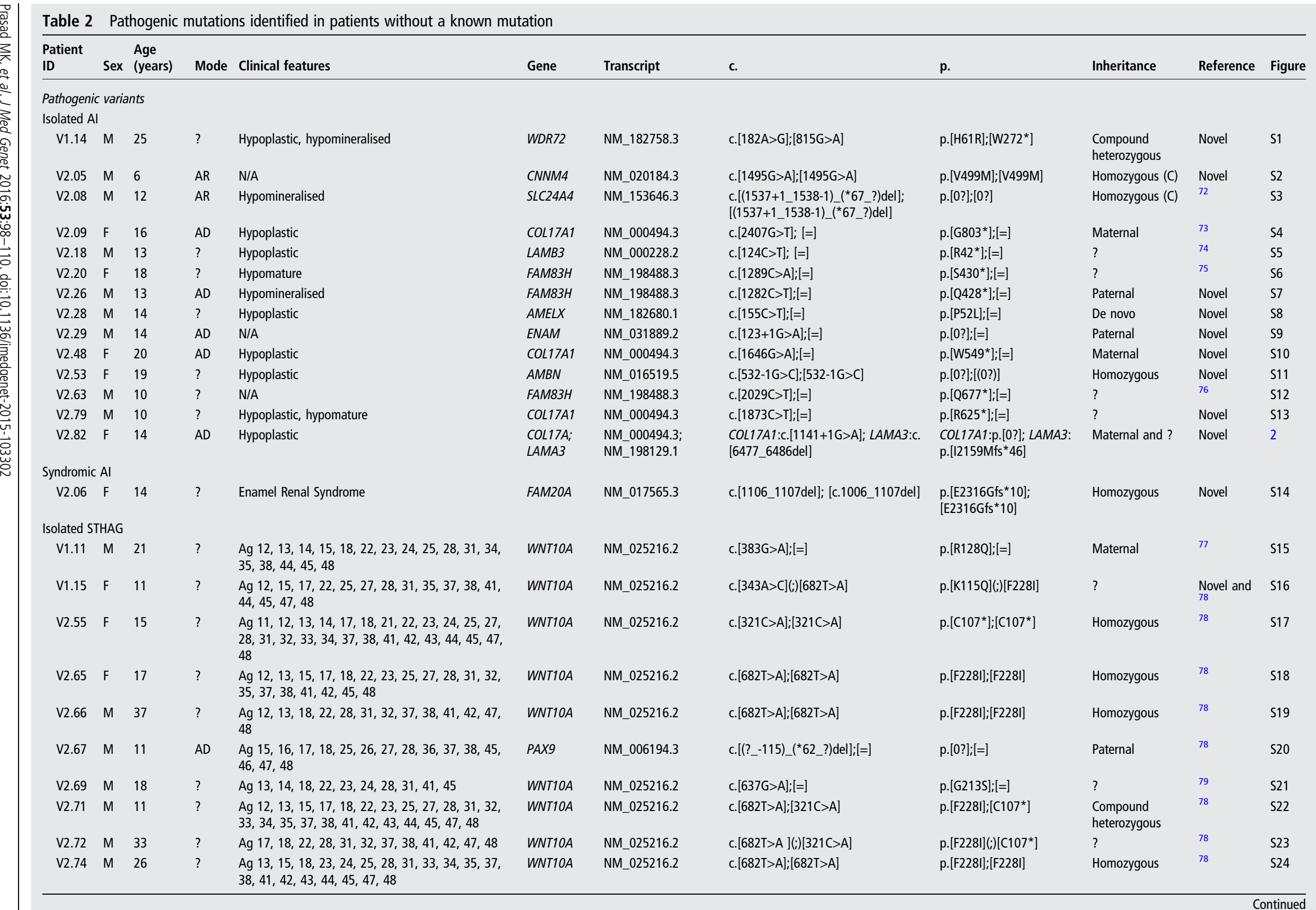


Table 2 Continued

\begin{tabular}{|c|c|c|c|c|c|c|c|c|c|c|c|}
\hline $\begin{array}{l}\text { Patient } \\
\text { ID }\end{array}$ & Sex & $\begin{array}{l}\text { Age } \\
\text { (years) }\end{array}$ & Mode & Clinical features & Gene & Transcript & c. & p. & Inheritance & Reference & Figure \\
\hline V2.76 & $\mathrm{M}$ & 15 & $?$ & $\begin{array}{l}\text { Ag } 12,14,15,18,22,24,25,28,31,34,35,37 \\
38,41,42,43,44,45,47,48\end{array}$ & WNT10A & NM_025216.2 & c. $[682 \mathrm{~T}>\mathrm{A}] ;[682 \mathrm{~T}>\mathrm{A}]$ & p.[F228I];[F228I] & Homozygous & 78 & S25 \\
\hline V2.78 & $\mathrm{F}$ & 9 & $?$ & $\mathrm{Ag} 12,14,22,31,32,35,41$ & $E D A$ & NM_001399.4 & c. $[467 \mathrm{G}>\mathrm{A}] ;[=]$ & p. [R156H];[=] & De novo & 17 & S26 \\
\hline V2.91 & $\mathrm{F}$ & 12 & $A D$ & $\operatorname{Ag} 14,15,24,2535,36,45,46$ & MSX1 & NM_002448.3 & c.[249del];[=] & p.[E84Rfs*76];[=] & Paternal & Novel & S27 \\
\hline V2.92 & M & 9 & $?$ & $\begin{array}{l}\text { Ag } 12,17,22,23,24,25,27,35,37,33,31,41 \text {, } \\
43,45,47\end{array}$ & WNT10A & NM_025216.2 & c. $[682 \mathrm{~T}>\mathrm{A}] ;[=]$ & p.[F2281];[=] & Maternal & 78 & $\mathrm{~S} 28$ \\
\hline V2.93 & M & 28 & $?$ & $\begin{array}{l}\mathrm{Ag} 14,15,18,25,27,28,32,34,35,37,38,44 \\
45,47,48\end{array}$ & WNT10A & NM_025216.2 & c. $[682 \mathrm{~T}>\mathrm{A}] ;[682 \mathrm{~T}>\mathrm{A}]$ & p.[F228I];[F228I] & Homozygous & 78 & S29 \\
\hline \multicolumn{12}{|c|}{ Syndromic STHAG } \\
\hline V2.54 & $\mathrm{F}$ & 49 & $?$ & ED & WNT10A & NM_025216.2 & c. $[682 \mathrm{~T}>\mathrm{A}] ;[\mathrm{c} .416 \mathrm{C}>\mathrm{T}]$ & p.[F2281];[p.A139V] & $\begin{array}{l}\text { Compound } \\
\text { heterozygous }\end{array}$ & $\begin{array}{l}78 \text { and } \\
\text { novel }\end{array}$ & S30 \\
\hline V2.87 & $\mathrm{F}$ & 3 & $?$ & Intellectual disability & CTNNB1 & NM_001904.3 & c.[998dup]; [=] & p. $\left[\operatorname{Tyr} 333^{*}\right] ;[=]$ & $?$ & Novel & S31 \\
\hline \multicolumn{12}{|c|}{ Isolated DGI/DD } \\
\hline V1.09 & $F$ & 10 & $A D$ & $\mathrm{DD}^{*}$ & $D S P P$ & NM_014208.3 & c.[3480del];[=] & p.[S1160Rfs*154];[=] & $?$ & Novel & S32 \\
\hline V1.10 & $M$ & 9 & $A D$ & $\mathrm{DGI}^{*}$ & $D S P P$ & NM_014208.3 & c.[3480del]; [=] & p.[S1160Rfs*154];[=] & Maternal & Novel & S32 \\
\hline V2.36 & M & 45 & $A D$ & DGI & DSPP & NM_014208.3 & c. [3533_3534insTA]; [=] & p.[N1179Tfs*136];[=] & ? & Novel & S33 \\
\hline V2.55 & $\mathrm{F}$ & 12 & $A D$ & DGI & DSPP & NM_014208.3 & c. $[52 \mathrm{G}>\mathrm{T}] ;[=]$ & p.[V18F];[=] & Maternal & 80 & S34 \\
\hline V2.57 & $\mathrm{F}$ & 44 & $A D$ & DGI & $D S P P$ & NM_014208.3 & c.[3480del];[=] & p. [S1160Rfs*154];[=] & $?$ & Novel & S35 \\
\hline V2.59 & $\mathrm{F}$ & 41 & $?$ & DGI & DSPP & NM_014208.3 & c.[3682_3686del];[=] & p. $\left[\mathrm{S} 1228^{*}\right] ;[=]$ & $?$ & Novel & S36 \\
\hline \multicolumn{12}{|c|}{ Syndromic DGI } \\
\hline V2.58 & M & 47 & $A D$ & Osteogenesis imperfecta & COL1A1 & NM_000088.3 & c.[3837_3840del];[=] & p.[N1279Lfs*51];[=] & Paternal & Novel & S37 \\
\hline \multicolumn{12}{|c|}{ Otodental syndrome } \\
\hline V2.03 & M & 13 & $A D$ & & FGF3 & NM_005247.2 & c.[(?_-3)_(220+1_221-1)del];[=] & p.[0?];[=] & Paternal & Novel & S38 \\
\hline
\end{tabular}

AD, autosomal dominant; Al, amelogenesis imperfecta; AR, autosomal recessive; C, consanguineous parents; DD, dentin dysplasia; DGI, dentinogenesis imperfecta; ED, ectodermal dysplasia; ID, intellectual disability; STHAG, selective tooth agenesis. 


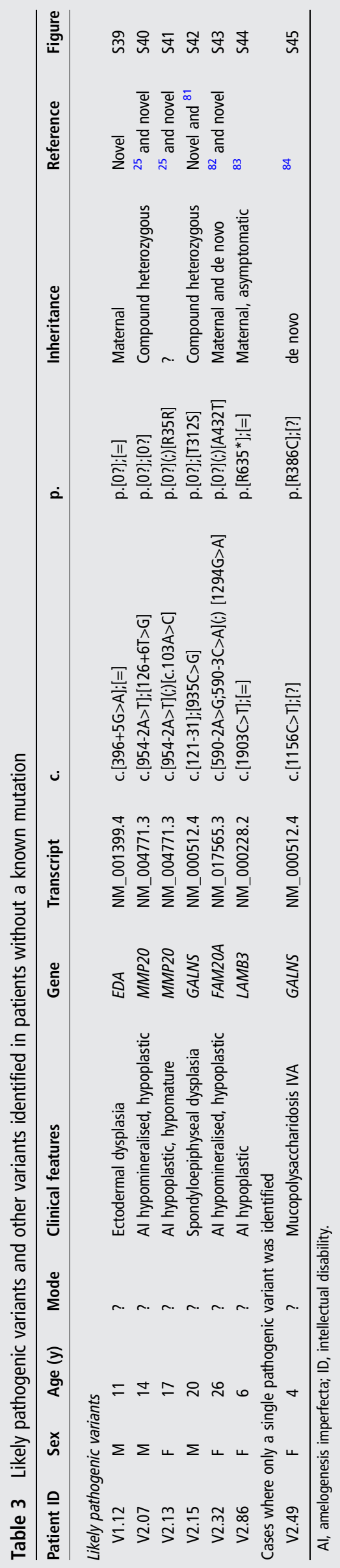

autosomal-recessive (AR) or X-linked fashion, the mode of transmission was unclear for the majority of cases. Sixty-six cases showed sporadic disease, whereas 35 showed familial transmission. The mode of inheritance could be confidently inferred only in 18 cases, 15 as $\mathrm{AD}$ due to the presence of other affected family members, 2 as AR due to the presence of consanguinity between the parents of the index case and 1 as $\mathrm{X}$-linked. Due to the large number of cases without a known mode of inheritance of disease, a common situation in diagnostic cohorts, variant filtration was performed for all samples for all modes of inheritance. Overall, we had a definitive molecular diagnosis in known genes in 39 cases (39\%) and discovered 21 novel pathogenic variants. All pathogenic mutations identified in this cohort are listed in table 2. Likely pathogenic mutations and other variants are shown in table 3 . The distribution of pathogenic variants identified with respect to the disease category and the number of cases corresponding to each mutated gene is shown in figure 1.

Isolated Al: COL17A1 mutations are a frequent cause of AI

Of the 50 unrelated cases with confirmed isolated AI, we identified the causative mutation in 14 cases (27\%). Surprisingly, the most frequently mutated gene in our cohort was COL17A1, with four independent patients segregating pathogenic mutations in this gene (of which three are novel). In the biallelic state, mutations in COL17A1, encoding a structural component of hemidesmosomes, cause junctional, non-Herlitz-type epidermolysis bullosa (EB), a skin blistering disorder with associated dental enamel defects. ${ }^{85}$ However, rare cases of isolated ADAI in heterozygous carriers have been reported. ${ }^{37} 86$ Similarly, heterozygous mutations in LAMA3 and LAMB3, which also encode hemidesmosomal components, can cause ADAI, whereas biallelic mutations in these genes cause EB. ${ }^{38} 39$ We found one family segregating a known heterozygous $L A M B 3$ nonsense mutation. These patients showed a similar enamel phenotype characterised by a hypoplastic form of AI with thin enamel and a characteristic pitting of the enamel that varied in severity (figures $2 \mathrm{~A}-\mathrm{H}$ and $3 \mathrm{C}$ ). Depending on the extent of pitting, the enamel surface was sometimes rough. Secondary extrinsic colouration of the pits rendered them more visible. Interestingly, patient V2.82 had two unlinked mutations, one maternally inherited novel COL17A1 splice mutation (c.1141 $+1 \mathrm{G}>\mathrm{A}$ ) and a novel $L A M A 3$ frameshift-inducing deletion (p.I2159Mfs*46) that is absent in her mother (figure 2I). The father of the patient was unavailable for testing but was described as unaffected at the time of ascertainment. The c. $1141+1 \mathrm{G}>\mathrm{A}$ mutation is predicted to cause either in-frame skipping of exon 14 (which encodes a part of the intracellular domain) or retention of intron 14 that would subsequently introduce a premature termination codon (PTC) and likely nonsense-mediated decay (NMD) of the transcript. Patient V2.82's enamel phenotype is more severe than that of her mother, suggesting digenic inheritance in this individual. Patient V2.82 has hypoplastic AI with clearly visible pitted enamel in the vestibular, lingual and palatal surfaces of premolars and molars and a white colouration following Retzius striae visible in the permanent incisors (figure 2A, B). Her mother's dentition, in contrast, shows more discrete signs of $\mathrm{AI}$ and fewer pits are visible on the buccal surfaces of premolars (figure 2C, D). Digenic mutations in $L A M B 3$ and COL17A1 that modify the severity of the EB phenotype have been previously reported. ${ }^{87}$ However, this is the first report of seemingly digenic inheritance in ADAI. 
Figure 1 Distribution of pathogenic variants identified by disease category. The genes in which pathogenic mutations were identified are shown with respect to the disease in which they were identified. In parentheses next to each gene is the number of independent patients in whom mutations were identified in the gene. This figure includes results from patients V1.09-V1.16 and V2.01V2.95. DD dentin dysplasia; DGI, dentinogenesis imperfecta; STHAG selective tooth agenesis.
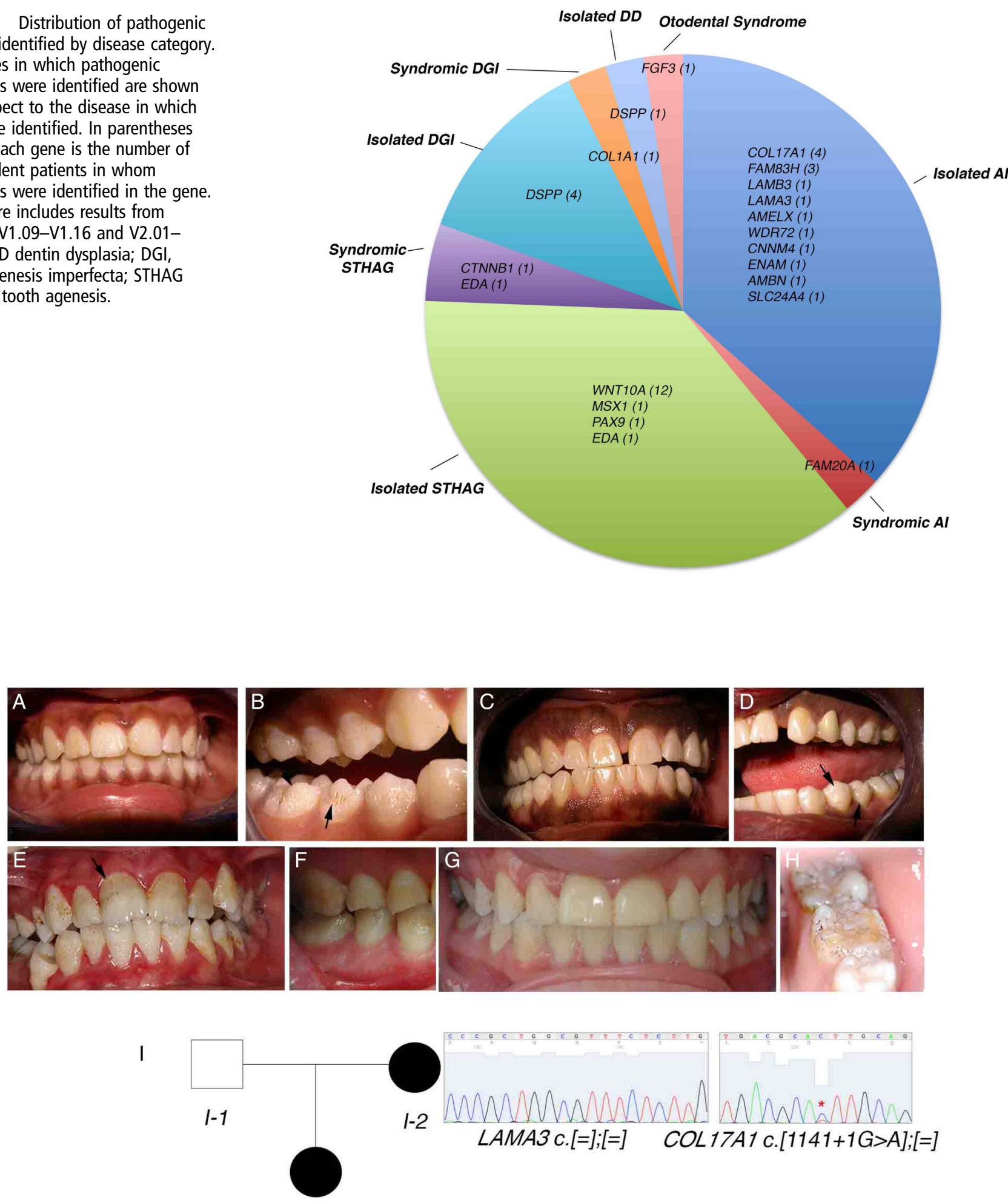

II-1 (Patient V2.82)

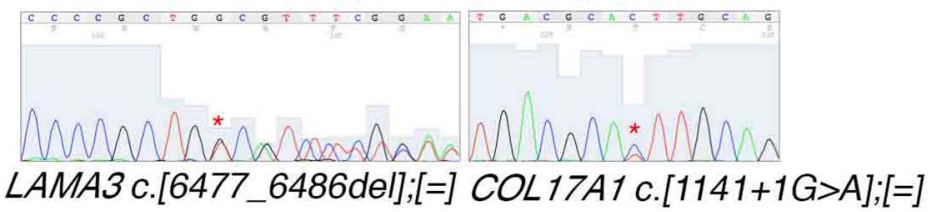

Figure 2 COL17A1 mutations show a characteristic enamel phenotype in autosomal-dominant amelogenesis imperfecta. (A-H) Photos of the enamel phenotypes of individuals with COL17A1 mutations. (A, B) Patient V2.82. (C, D) Mother of patient V2.82. (E, F) Patient V2.09. (G, H) Patient V2.48. Arrows mark pits in the enamel that are characteristic of COL17A1 mutations. Extrinsic colouration makes these pits more visible in (B), (E) and $(\mathrm{H})$. (I) Seemingly digenic inheritance of amelogenesis imperfecta in patient V2.82. Asterisks on the sequence chromatograms mark the mutated nucleotides. 

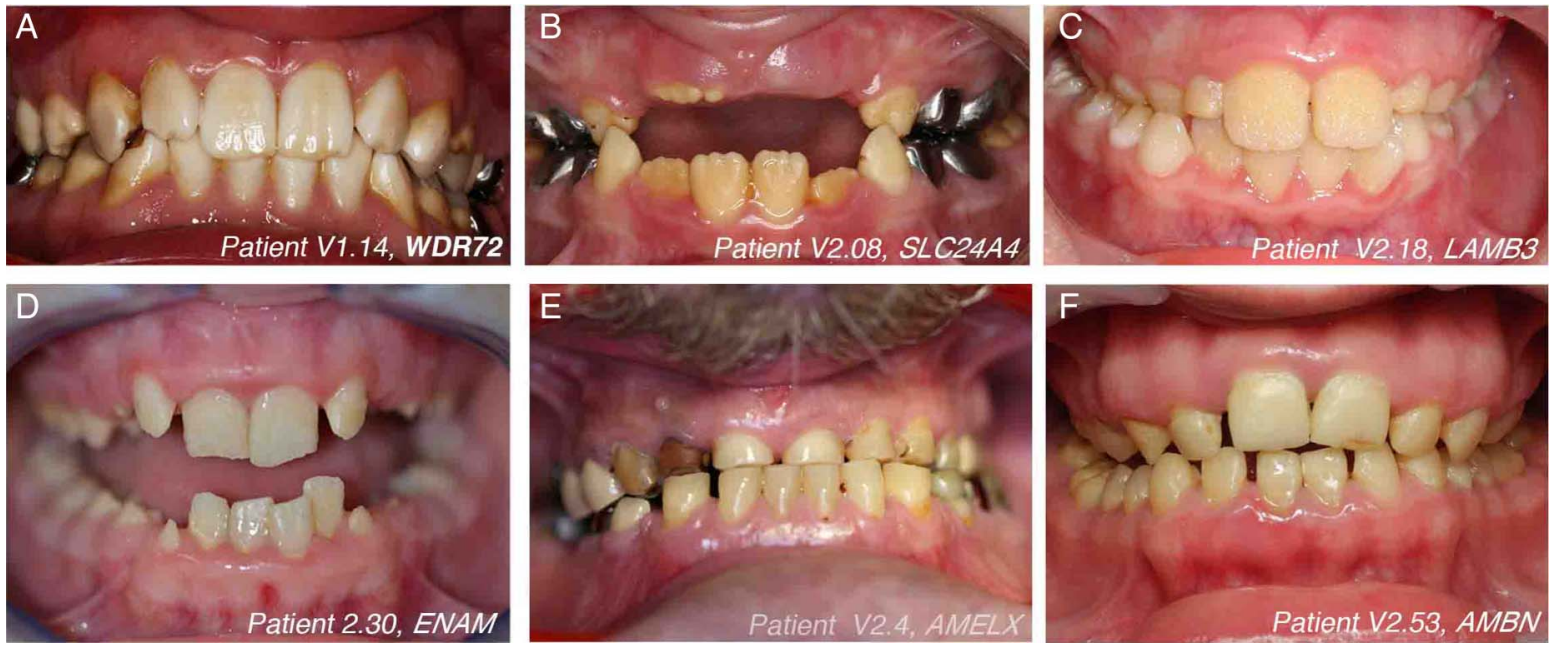

Figure 3 The variety of isolated amelogenesis imperfecta phenotypes seen in this cohort. Representative images of the enamel phenotype associated with mutations in different genes. The mutated gene and patient number are indicated in each panel.

We also identified a family with a novel homozygous splicesite mutation (c.532-1G>C) in $A M B N$. To date, only a single family has been reported to carry mutations in this gene. ${ }^{27}$ Similar to the patients in the initial study, our patient too exhibited hypoplastic AI with very limited enamel as seen in the unrestored yellow-tinged premolars and permanent molars. However, the tooth surfaces did not seem as pitted as described previously (figure $3 \mathrm{~F}$ ). ${ }^{27}$ This mutation is predicted to alter mRNA splicing by inducing either the skipping of exon 7 or the retention of intron 6. Exon skipping would lead to in-frame deletion of exon 7, which encodes a domain involved in heparin and fibronectin interaction that is thought to be important for the interaction of $A M B N$ with dental epithelial cells. ${ }^{88} 89$ Intron retention would introduce a PTC that is likely to cause NMD of the mRNA. Additionally, a cryptic acceptor splice-site is predicted bioinformatically to be activated in exon 7 that would cause partial out-of-frame skipping of exon 7 and a subsequent PTC (see online supplementary figure S11). Thus, this mutation is predicted to cause at least a partial loss of $A M B N$ function. We also identified novel mutations in WDR72, $A M E L X$ and ENAM, and a known deletion of the last three exons of SLC24A4 (table 1). Representative images of the enamel phenotype associated with mutations in each gene are shown in figure 3. Similar to previous reports, WDR72 and SLC24A4 mutations caused hypomineralised, hypomature AI with brownish/yellowish discoloured teeth. ${ }^{22} 29$ The enamel showed a lack of contrast with the underlying dentin upon X-ray imaging (data not shown). The softer enamel seen in the patient with WDR72 mutations was subject to wear, whereas the enamel in the patient with the SLC24A4 mutation was opaque. Patients with AMELX, LAMB3 and ENAM mutations had hypoplastic AI with yellow discolouration and smaller teeth due to thinner enamel.

Interestingly, we identified a novel homozygous missense mutation (p.V499M) in CNNM4 in patient V2.05 who was born to first-cousins and was referred for isolated AI. This mutation affects a highly conserved residue in a functional cystathionine beta-synthase domain of the protein and is predicted bioinformatically by three algorithms (SIFT, PolyPhen and MutationTaster) to be deleterious (see online supplementary figure S2). However, mutations in this gene are known to cause Jalili syndrome, which is characterised by a combination of AI and cone-rod dystrophy. ${ }^{33}{ }^{90} \mathrm{~A}$ subsequent full-field electroretinography revealed a marked loss of cone response and a less severe loss of rod response in the patient, thus confirming the Jalili phenotype (see online supplementary figure S2E, F).

\section{Syndromic Al}

We confirmed the molecular diagnosis in one case of Enamel Renal Syndrome (patient V2.06). This patient was homozygous for a novel frameshift-inducing deletion in FAM20A (c.1106_1107del).

In patient V2.15, referred for the management of AI in the context of suspected spondyloepiphyseal dysplasia (SED), we identified a known pathogenic missense mutation (p.T312S) and a likely pathogenic intronic variant (c.121-31) in GALNS (mutated in mucopolysaccharidosis (MPS) IVA) predicted to create an intronic splice enhancer (see online supplementary figure S42). However, the biological effect of this intronic mutation warrants further investigation. No deleterious mutations were identified in CHST3 or COL2A1 and a differential diagnosis of mucolipidosis type III was eliminated due to normal hexosaminidase, alpha-L-fucosidase and beta-D-glucuronidase levels (data not shown). Similar clinical presentation of SED and MPS IVA has been previously demonstrated $;^{91}$ therefore, our results suggest a potential differential diagnosis of MPS IVA in this patient. In the case of patient V2.49, referred for the management of AI linked to MPS IVA, ${ }^{92} 93$ we identified only a single de novo known pathogenic mutation in GALNS (p.R386C), suggesting the presence of a second mutation in intronic or regulatory regions, or a structural mutation missed by our pipeline. The presence of an undetected second mutation is consistent with the virtually absent GALNS activity in the patient's leucocytes ( $1 \mathrm{nmol} / \mathrm{h} / \mathrm{mg}$ protein) (data not shown). Both these patients exhibited hypoplastic AI with thin striated and pitted enamel and subsequently flattened buccal surfaces (see online supplementary figure S45) consistent with previous reports of the enamel phenotype seen in MPS IVA, ${ }^{94}$ further supporting a diagnosis of MPS IVA in both patients. However, additional tests are necessary to confirm this diagnosis.

\section{Isolated and syndromic STHAG}

We identified the causative mutation in 15/21 (71\%) cases of isolated STHAG. The majority carried mutations in WNT10A either in a heterozygous, homozygous or compound 
heterozygous state as has been previously reported. ${ }^{77} \quad 79$ Fortuitously, we were also able to provide a molecular diagnosis for a patient presenting with ID who was referred for the management of hypodontia. The patient (V2.87) had agenesis of five incisors, two maxillary incisors and three mandibular permanent incisors (agenesis 12, 22, 41, 31 and 32) and had no family history of hypodontia or ID. We identified a novel heterozygous nonsense mutation in CTNNB1 (p.Tyr333*), which encodes beta-catenin, a member of the WNT signalling pathway, which is essential during multiple stages of tooth development. ${ }^{95}$ Recent reports have established a role for heterozygous CTNNB1 mutations in ID characterised by mild to severe ID, autism spectrum disorder childhood hypotonia with progressive spastic diplegia, microcephaly and significant additional craniofacial and brain abnormalities, which is compatible with this patient's phenotype (data not shown). ${ }^{96} 97$ However, the orodental phenotype in this syndrome has not been studied in detail. Our report suggests that patients with ID due to CTNNB1 mutations may require a dental examination and management of hypodontia. Furthermore, this case highlights the benefit of an interdisciplinary approach to patient care and the potential utility of a full dental examination in syndromes with craniofacial involvement.

\section{Dentinogenesis imperfecta and dentin dysplasia}

Among the six independent cases of isolated dentin disorders, we identified the causative mutation in five. All patients carried mutations in DSPP, the only gene implicated thus far in isolated DD/DGI. ${ }^{2}$ The majority of mutations were present in the repeat-rich exon 5 that is often refractory to Sanger sequencing and hence until now excluded from routine diagnostic sequencing. ${ }^{98}$ We achieved an average coverage of $771 \times$ and $408 \times$ over exon 5 of DSPP with v1.0 and v2.0, respectively. Hence, our assay provides an effective means to screen for mutations in the last exon of DSPP. Our bioinformatic pipeline detected the majority of mutations; however, one mutation (c.3682_3686del) was missed due to the difficulty of calling variants in structurally complex regions (personal communication, MKP, Broad Institute GATK Team), but was detected upon visual inspection of the reads. We also identified a novel frameshift-inducing deletion in COL1A1 in a family segregating $\mathrm{AD}$ osteogenesis imperfecta with DGI.

\section{Otodental dysplasia}

We identified a heterozygous deletion of the first exon of FGF3 in a family segregating suspected AD otodental dysplasia, which is characterised by globodontia and hearing loss, sometimes segregating with colobomas, most likely due to the deletion of the adjacent FADD gene. ${ }^{99}$ This deletion was validated by qPCR on genomic DNA, which showed the presence of the deletion in patient V2.03 as well as in his affected father (see online supplementary figure S38).

\section{DISCUSSION}

We have developed a targeted NGS assay for the diagnosis and discovery of mutations underlying rare genetic disorders with orodental manifestations. We achieved high sequencing coverage in the targeted regions, $179 \times$ average coverage with $97.2 \%$ of the targeted region covered at $\geq 20 \times$ with V.2.0. In a cohort of 101 unrelated patients with a variety of orodental genetic disorders of unknown genetic aetiology, we were able to detect the underlying pathogenic mutation in 39 cases (39\%) in known genes.
Targeted NGS gene panels are being widely used for the diagnosis of a variety of genetic disorders, including ID, mitochondrial disorders and neuromuscular diseases. ${ }^{42-44}$ However, to the best of our knowledge, this is the first report of a targeted NGS gene panel for orodental disorders. Therefore, this diagnostic tool responds to a veritable need within the dental genetics community. Furthermore, two concrete examples from our cohort suggest the utility of this tool to the wider medical genetics community. First, we were able to diagnose a mutation in CTNNB1 in a patient with ID and tooth agenesis, suggesting the potential utility of our assay in screening for mutations in ID cases with orodental involvement. Second, the detection of a CNNM4 mutation in a patient referred for isolated AI led to an ophthalmological investigation for cone-rod dystrophy and the confirmation of Jalili syndrome. These cases highlight how the oral consultation can be a port of entry for the diagnosis and management of patients with rare genetic diseases, especially in light of the involvement of the same genes in syndromic and isolated forms of orodental disease and the sometimes non-evident extra-oral signs associated with some diseases.

Our targeted NGS panel targets fewer genes than WES/WGS and may thus exclude potential disease-causing genes. Yet, it has several advantages in a clinical setting. First, it provides higher sequencing coverage in the targeted regions than WES/WGS. A comparison of the coverage of the same regions achieved with v2.0 of our gene panel and a commercially available WES kit demonstrates that the coverage from WES falls short of the requirements for confident molecular diagnosis, that is, only $89.09 \%$ of targets covered at $\geq 20 \times$ with WES vs $97.23 \%$ of targets covered at $\geq 20 \times$ with our panel (see online supplementary figure S46 and table S8). Second, due to the smaller number of variants identified by targeted sequencing ( 2600 variants with our panel vs $\sim 30000$ with WES), variant interpretation is relatively simpler. This is also true for CNVs-we were able to detect and validate a single exon deletion in FGF3. Finally, the cost, amount of time for data analysis and interpretation, and data storage requirements are lower with targeted NGS than with WES/WGS approaches, making it an attractive alternative for clinical implementation. Alternatively, our assay could serve as a primary mutation-screening tool to exclude mutations in known genes before performing WES/WGS.

We expected that the inclusion of candidate genes selected based on their expression in developing mouse teeth ${ }^{50}$ and their implication in animal models of orodental disorders would permit the identification of novel genes mutated in these disorders. In order to identify potentially novel genes in patients lacking mutations in known genes, we performed a preliminary analysis focusing on rare loss-of-function variants (nonsense, invariant splice site and frameshift variants) that were present in the same gene in at least two independent families with the same phenotype. Such a strategy was previously used successfully to identify a novel gene, SETD5, in ID. ${ }^{100}$ However, this preliminary analysis did not yield any positive findings. Indeed, this analysis was limited in that it did not consider missense mutations whose effect is less clear and was complicated by the lack of information regarding the mode of inheritance in the majority of cases. Also, in this analysis patients were regrouped by disease category (all mutation-negative AI patients, all mutation-negative STHAG patients) without subclassification based on fine phenotype (eg, hypoplastic vs hypomineralised AI and severity of STHAG), which may be important to include in order to overcome the difficulties posed by genetic heterogeneity. ${ }^{101}$ Furthermore, the rarity of mutations in some genes may also necessitate much larger cohorts. Indeed, future analyses of this cohort will try to address these limitations. 
Among the 50 unrelated patients with confirmed isolated AI in our cohort, we had a molecular diagnosis rate of $27 \%$. This is slightly lower than the diagnostic rates reported by other studies that performed candidate gene sequencing in large AI cohorts. By performing Sanger sequencing of six genes (FAM83H, ENAM, AMELX, MMP20, KLK4 and WDR72) in 71 families, Wright et $a l^{75}$ identified mutations in 26 families (37\%). By sequencing the same six genes in an independent cohort of 39 AI kindreds, Chan et al ${ }^{102}$ identified mutations in 19 kindreds (49\%). In the latter study, the diagnostic rate was shown to be dependent on the mode of transmission: $\mathrm{X}$-linked $>\mathrm{AD}>\mathrm{AR}>$ simplex cases. In our study, the majority of cases were simplex cases (31 cases), which may explain to a degree our lower diagnostic rate despite the inclusion of a larger number of known AI genes. Furthermore, the 50 patients selected for this study belong to a larger AI cohort of 71 patients, a part of which (including patients in this study) had been previously sequenced by candidate gene Sanger sequencing and in which mutations were identified in 11 patients ${ }^{103}$ (online supplementary table S3 and unpublished data). Therefore, the overall diagnostic rate in the 71-patient cohort is 35\% (25 patients), which is closer to published diagnostic rates. In further contrast to the above-mentioned studies where FAM83H was the most frequently mutated gene in ADAI, COL17A1 was the most frequently mutated gene in ADAI in our cohort, with $8 \%$ of our AI cohort carrying deleterious mutations in COL17A1. Additionally, we demonstrate that the presence of unlinked mutations in COL17A1 and LAMA3 can modify the severity of AI, suggesting a digenic mode of AI inheritance associated with mutations in the hemidesmosomal components. Therefore, our findings are novel in demonstrating the frequency of COL17A1 mutations in ADAI. Finally, the large number of AI patients without mutations in known genes suggests that the genetic and allelic heterogeneity underlying $\mathrm{AI}$ is yet to be fully unravelled.

The diagnostic rate in syndromic AI was low in our cohort (7\%). This is likely because of the inclusion of patients without a clear clinical diagnosis. These cases likely represent novel phenotypes with mutations in novel genes. Thus, WES may be better suited for such cases. Yet, the identification of a single de novo pathogenic mutation in GALNS in patient V2.49 can inform genetic counselling in this family. Similarly, the identification of one pathogenic and one potentially pathogenic mutation in GALNS in patient V2.15 permits an evidence-based investigation of MPS IVA by assaying leucocyte GALNS activity. ${ }^{104}$ Therefore, although sequencing did not provide a definitive molecular diagnosis in these cases, the results of this assay can contribute to orienting clinical investigations/counselling.

Among the 21 cases of isolated STHAG, we identified the causative mutation in 15 (71\%). This diagnostic rate is comparable to that reported in the literature. By screening WNT10A, MSX1, PAX9, IRF6 and AXIN2 by Sanger sequencing in 34 patients with isolated hypodontia, van den Boogaard et $a l^{77}$ were able to identify the underlying mutation in $71 \%$ of cases. Similar to other reports, WNT10A accounted for the majority of mutations in our cohort (52\%) and were also associated with ectodermal dysplasia (patient V2.54), with F228I, similar to other reports, being the most commonly mutated allele in our cohort, consistent with its population frequency $(2.4 \%$ in European-Americans) and the prevalence of STHAG in this population $(4.2 \%) .^{77-79} 105106$

In conclusion, we have developed the first targeted NGS gene panel for the diagnosis and discovery of mutations in genetic disorders with orodental involvement. This panel can be reliably used for the molecular diagnosis in known genes of a variety of genetic disorders and can serve as a primary screening tool before the application of WES/WGS. Additionally, this panel also provides the potential for the discovery of novel genes mutated in orodental disorders.

\section{Author affiliations}

${ }^{1}$ Laboratoire de Génétique Médicale, INSERM U1112, Institut de génétique médicale d'Alsace, FMTS, Université de Strasbourg, Strasbourg, France

${ }^{2}$ Plateforme de Biopuces et Séquençage, Institut de Génétique et de Biologie Moléculaire and Cellulaire-Centre Européen de Recherche en Biologie et en

Médecine, CNRS UMR7104, INSERM U964, Université de Strasbourg, Illkirch, France ${ }^{3}$ Centre de Référence des Manifestations Odontologiques des Maladies Rares, Pôle de Médecine et Chirurgie Bucco-dentaires, Hôpitaux Universitaires de Strasbourg (HUS), Strasbourg, France

${ }^{4}$ Faculté de Chirurgie Dentaire, Université de Strasbourg, Strasbourg, France

${ }^{5}$ Evolution et Développement du Squelette-EDS, UMR7138-SAE, Université Pierre et

Marie Curie, Paris, France

${ }^{6}$ Institut de Génétique et de Biologie Moléculaire and Cellulaire-Centre Européen de Recherche en Biologie et en Médecine, CNRS UMR7104, INSERM U964 Université de Strasbourg, Illkirch, France

${ }^{7}$ Faculté de Médecine, CHU de Nancy, Université de Lorraine, Vandoeuvre-Les-

Nancy, France

${ }^{8} \mathrm{CHU}$ de Nancy, Service d'Odontologie, Nancy, France

${ }^{9}$ Départment d'Odontologie Pédiatrique, UFR d'Odontologie, Université de Nice

Sophia-Antipolis, CHU de Nice, Nice, France

${ }^{10}$ URB2i-EA 4462, Paris Descartes, Paris, France

${ }^{11}$ Faculté de Chirurgie Dentaire, Département d'Odontologie Pédiatrique, CHU Hotel

Dieu, Service d'odontologie conservatrice et pédiatrique, Nantes, France

${ }^{12}$ Faculté de Chirurgie Dentaire, Département d'Odontologie Pédiatrique, Université

Paris Descartes, Montrouge, France

${ }^{13}$ Institute of Human Genetics, Heidelberg University, Heidelberg, Germany

${ }^{14}$ Service de Consultations et Traitements Dentaires, Hospices Civils de Lyon, Faculté d'Odontologie, Université Claude Bernard Lyon1, Lyon, France

${ }^{15}$ Service de Génétique Clinique, CHU de Rennes, Rennes, France

${ }^{16}$ Faculté de Chirurgie Dentaire, CHU de Toulouse, Odontologie Pédiatrique,

Université Paul Sabatier, Toulouse, France

${ }^{17}$ Unité Fonctionnelle d'Odontologie pédiatrique, Service d'odontologie, CHRU de Lille, Lille, France

${ }^{18}$ Faculté de Chirurgie Dentaire, Service d'Odontologie Conservatrice et Endodontie, CHU Nantes, Université de Nantes, France

${ }^{19}$ Service de Génétique, CHU Tours, Tours, France

${ }^{20}$ Départment d'Odontologie Pédiatrique, Université de Nice Sophia-Antipolis, CHU Nice, Nice, France

${ }^{21}$ Service de Génétique Médicale, CHU Nice, Nice, France

${ }^{22}$ Pôle de Médecine et de Chirurgie Bucco-dentaire, Hôpital Civil, HUS, Strasbourg,

France

${ }^{23}$ Faculty of Dental Medicine, Department of Pediatric Dentistry, University

Mohammed $V$ Rabat, Morocco

${ }^{24}$ Pédiatrie 1, Hôpitaux Universitaires de Strasbourg, Strasbourg, France

${ }^{25}$ Département de Pédiatrie, CHU de Lyon, Lyon, France

${ }^{26}$ Service de génétique clinique Guy Fontaine, Centre Hospitalier Régionale Universitaire (CHRU) de Lille, Lille, France

${ }^{27}$ Service de Génétique Médicale, CHU de Strasbourg, Strasbourg, France

${ }^{28}$ Klinik für Zahnerhaltungskunde und Parodontologie, Universitats Klinikum,

Freiburg, Germany

${ }^{29}$ Service de Génétique, Centre Hospitalier de Mulhouse, Mulhouse, France

${ }^{30}$ Laboratoire de Physiopathologie Orale Moléculaire INSERM UMR S1138, Centre de Recherche des Cordeliers, Universités Paris-Diderot et Paris-Descartes, Paris, France

${ }^{31}$ Centre de Référence des Malformations Rares de la Face et de la Cavité Buccale MAFACE, Hôpital Rothschild, Pôle d'Odontologie, Paris, France

${ }^{32}$ Aix-Marseille Université, UMR 7268 ADES/EFS/CNRS, APHM, Hôpital Timone, Service Odontologie, Marseille, France

${ }^{33}$ Service de Génétique Médicale, Centre de Référence pour les Affections Rares en Génétique Ophtalmologique, HUS, Strasbourg, France

Acknowledgements The authors would like to thank all patients and their families for participating in this study. They also thank Ms Vanessa Stoehr for administrative help, Dr Mathilde Huckert and Jorel Salomon for technical assistance, Drs Elise Schaefer and Sophie Scheidecker for help with obtaining clinical data, and Dr Yaumara Perdomo-Trujillo for the electroretinography examination. They would like to thank Drs Alain Verloes, Jean-Yves Sire, Jean-Pierre Clavert, Béatrice Walter, Patrick Lutz, André Nirrengarten, Isabelle Rian, Thibault Sibert, Laurence Lustig-Grimm, Daniel Jasiak, James Lespinasse, Jacques Hassid, Smail Hadj-Rabia, Gabriel Dominici, Laurent Riguet, Dan Lipsker, Jean Luc Alessandri, Florence Rousselet, Philippe Schoenlaub, François Serres, Etienne Mornet, Thomas Edouard, 
Bertrand Baumann, Klaus Dietrich, Yves Bolender, Sandra Mercier, Elisabeth Steichen-Gersdorf, Jean-Gabriel Chillès, Hadrien Bonomi Dunoyer, Philippe Jonveaux, Supawich Morkumed, Patimaporn Pungchanchaikul, Sameh Mabrouk, Noora Zouari, Ithame Mamouni, Alicia Rossa, Caroline Delfosse, Sylvie Goldmann, Esther Levy, Pierre Wahl, Jean-Claude Schoeffler, François Charton, Pascale Meng, Pierre-Emile Spaeth, Marie-Claude Addor, Rene Serfaty, Anthony Kurtz, Renaud Rinkenbach, Alain Duret, Jehan Figier, Denys Chaigne, Marc Hildwein, Florence Jouanet, Olivier Grison, Marie-Noelle Duffard, Gautier Jouvenet Gilquin, Francois Undreiner, Gabrielle Baver, Isabelle Zumsteeg, Cloé Vorpahl, Alain Burtscher, Michel Kretz, Cyrielle Marc, Jean-Pierre Strauss, Elise Pilavyan, Pierre Bonnaure, and Celine Benarroch-Leininger, Rémy Mathis, William Bacon, Marie-Rose Javier, Bilal Ahmed and Elia Sfeir for referring patients. Sequencing was performed by the IGBMC Microarray and Sequencing platform, a member of the 'France Génomique' consortium (ANR-10-INBS-0009).

Contributors Study concept and design: MKP, $H D$ and $A B-Z$. Patient inclusion: $M S, B L, D D, A D, A L, B G, M M-B, S L C, M M, S J, F O, V V, J-L D, T D-B, A-S K, U M, B R$, $J-J M, J-P D, S O, I B-F, M M R, L M, A T, C J, F G, J-C D, A C, M E A, S L, S S, N G, A D, B D$, $S F, E G, B F, M D M, Y A, C T, F C, A B, M C M, H D$ and $A B-Z$. Data generation, analysis and interpretation: MKP, VG, SV, BJ, MD, SLG, VL-H, BG, MP, CS and AB-Z. Drafting of the manuscript: MKP and AB-Z. Critical reading of the manuscript: UM, $A B$ and $H D$.

Funding This work was supported by grants from the French Ministry of Health (National Program for Clinical Research, PHRC 2008 N4266 Amelogenesis imperfecta), the University Hospital of Strasbourg (API, 2009-2012, 'Development of the oral cavity: from gene to clinical phenotype in Human') and the EU-funded project (ERDF) A27 'Oro-dental manifestations of rare diseases,' supported by the RMT-TMO Offensive Sciences initiative, INTERREG IV Upper Rhine programme. http://www.genosmile.eu

\section{Competing interests None declared.}

Patient consent Obtained.

Ethics approval French Ministry of Higher Education and Research (MESR).

Provenance and peer review Not commissioned; externally peer reviewed.

Data sharing statement All PCR primers and protocols are available upon request from the corresponding author.

Open Access This is an Open Access article distributed in accordance with the Creative Commons Attribution Non Commercial (CC BY-NC 4.0) license, which permits others to distribute, remix, adapt, build upon this work non-commercially, and license their derivative works on different terms, provided the original work is properly cited and the use is non-commercial. See: http://creativecommons.org/ licenses/by-nc/4.0/

\section{REFERENCES}

1 Polder BJ, Van't Hof MA, Van Der Linden FP, Kuijpers-Jagtman AM. A meta-analysis of the prevalence of dental agenesis of permanent teeth. Community Dent Oral Epidemiol 2004;32:217-26.

2 de La Dure-Molla M, Philippe Fournier B, Berdal A. Isolated dentinogenesis imperfecta and dentin dysplasia: revision of the classification. Eur J Hum Genet 2015;23:445-51

3 Brook AH. A unifying aetiological explanation for anomalies of human tooth number and size. Arch Oral Biol 1984;29:373-8.

4 Brook AH, Smith JM. The aetiology of developmental defects of enamel: a prevalence and family study in East London, UK. Connect Tissue Res 1998;39:151-6; discussion 87-94.

5 Alaluusua S, Lukinmaa PL. Developmental dental toxicity of dioxin and related compounds - a review. Int Dent J 2006;56:323-31.

6 Koch G. Prevalence of enamel mineralisation disturbances in an area with 1-1.2 ppm $\mathrm{F}$ in drinking water. Review and summary of a report published in Sweden in 1981. Eur J Paediatr Dent 2003;4:127-8.

7 Bloch-Zupan A, Sedano H, Scully C. Dento/oro/craniofacial anomalies and genetics. 1st edn. Boston, MA: Elsevier, 2012.

8 Cobourne MT, Sharpe PT. Diseases of the tooth: the genetic and molecular basis of inherited anomalies affecting the dentition. Wiley Interdiscip Rev Dev Biol 2013;2:183-212.

9 Crawford PJ, Aldred M, Bloch-Zupan A. Amelogenesis imperfecta. Orphanet J Rare Dis 2007;2:17.

10 Hennekam RCM, Allanson JE, Krantz ID, Gorlin RJ. Gorlin's syndromes of the head and neck. 5th edn. Oxford; New York: Oxford University Press, 2010.

11 Bergendal B, Klar J, Stecksén-Blicks C, Norderyd J, Dahl N. Isolated oligodontia associated with mutations in EDARADD, AXIN2, MSX1, and PAX9 genes. Am J Med Genet A 2011;155A:1616-22.

12 Lammi L, Arte S, Somer M, JäRvinen H, Lahermo P, Thesleff I, Pirinen S, Nieminen P. Mutations in AXIN2 cause familial tooth agenesis and predispose to colorectal cancer. Am J Hum Genet 2004;74:1043-50.
13 Noor A, Windpassinger C, Vitcu I, Orlic M, Arshad Rafiq M, Khalid M, Nasir Malik M, Ayub M, Alman B, Vincent JB. Oligodontia is caused by mutation in LTBP3, the gene encoding latent TGF-beta binding protein 3. Am J Hum Genet 2009:84:519-23.

14 Stockton DW, Das P, Goldenberg M, D'souza RN, Patel PI. Mutation of PAX9 is associated with oligodontia. Nat Genet 2000;24:18-19.

15 Tao R, Jin B, Guo SZ, Qing W, Feng GY, Brooks DG, Liu L, Xu J, Li T, Yan Y, He L. A novel missense mutation of the EDA gene in a Mongolian family with congenital hypodontia. J Hum Genet 2006;51:498-502.

16 Vastardis H, Karimbux N, Guthua SW, Seidman JG, Seidman CE. A human MSX1 homeodomain missense mutation causes selective tooth agenesis. Nat Genet 1996;13:417-21.

17 Monreal AW, Zonana J, Ferguson B. Identification of a new splice form of the EDA1 gene permits detection of nearly all X-linked hypohidrotic ectodermal dysplasia mutations. Am J Hum Genet 1998;63:380-9.

18 Cluzeau C, Hadj-Rabia S, Jambou M, Mansour S, Guigue P, Masmoudi S, Bal E, Chassaing $N$, Vincent $M-C$, Viot $G$, Clauss $F$, Manière $M-C$, Toupenay $S$, Le Merrer $M$, Lyonnet $S$, Cormier-Daire V, Amiel J, Faivre L, De Prost $Y$, Munnich A, Bonnefont J-P, Bodemer C, Smahi A. Only four genes (EDA1, EDAR, EDARADD, and WNT10A) account for $90 \%$ of hypohidrotic/anhidrotic ectodermal dysplasia cases. Hum Mutat 2011;32:70-2.

19 Jumlongras D, Bei M, Stimson JM, Wang W-F, Depalma SR, Seidman CE, Felbor U, Maas R, Seidman JG, Olsen BR. A nonsense mutation in MSX1 causes Witkop syndrome. Am J Hum Genet 2001;69:67-74.

20 Monreal AW, Ferguson BM, Headon DJ, Street SL, Overbeek PA, Zonana J. Mutations in the human homologue of mouse $\mathrm{dl}$ cause autosomal recessive and dominant hypohidrotic ectodermal dysplasia. Nat Genet 1999;22:366-9.

21 Rajpar MH, Harley K, Laing C, Davies RM, Dixon MJ. Mutation of the gene encoding the enamel-specific protein, enamelin, causes autosomal-dominant amelogenesis imperfecta. Hum Mol Genet 2001;10:1673-7.

22 El-Sayed W, Parry DA, Shore RC, Ahmed M, Jafri H, Rashid Y, Al-Bahlani S, Al Harasi S, Kirkham J, Inglehearn CF, Mighell AJ. Mutations in the beta propeller WDR72 cause autosomal-recessive hypomaturation amelogenesis imperfecta. Am J Hum Genet 2009;85:699-705.

23 Hart PS, Hart TC, Michalec MD, Ryu OH, Simmons D, Hong S, Wright JT. Mutation in kallikrein 4 causes autosomal recessive hypomaturation amelogenesis imperfecta. J Med Genet 2004:41:545-9.

24 Lagerström M, Dahl N, Nakahori Y, Nakagome Y, BäCkman B, Landegren U, Pettersson U. A deletion in the amelogenin gene (AMG) causes X-linked amelogenesis imperfecta (AlH1). Genomics 1991;10:971-5.

25 Kim JW, Simmer JP, Hart TC, Hart PS, Ramaswami MD, Bartlett JD, Hu JC. MMP-20 mutation in autosomal recessive pigmented hypomaturation amelogenesis imperfecta. J Med Genet 2005;42:271-5.

26 Kim JW, Lee SK, Lee ZH, Park J-C, Lee K-E, Lee M-H, Park J-T, Seo B-M, Hu JC-C, Simmer JP. FAM83H mutations in families with autosomal-dominant hypocalcified amelogenesis imperfecta. Am J Hum Genet 2008;82:489-94.

27 Poulter JA, Murillo G, Brookes SJ, Smith CEL, Parry DA, Silva S, Kirkham J, Inglehearn CF, Mighell AJ. Deletion of ameloblastin exon 6 is associated with amelogenesis imperfecta. Hum Mol Genet 2014;23:5317-24.

28 Poulter JA, Brookes SJ, Shore RC, Smith CEL, Abi Farraj L, Kirkham J, Inglehearn CF, Mighell AJ. A missense mutation in ITGB6 causes pitted hypomineralized amelogenesis imperfecta. Hum Mol Genet 2014;23:2189-97.

29 Parry DA, Poulter JA, Logan CV, Brookes SJ, Jafri H, Ferguson CH, Anwari BM Rashid Y, Zhao H, Johnson CA, Inglehearn CF, Mighell AJ. Identification of mutations in SLC24A4, encoding a potassium-dependent sodium/calcium exchanger, as a cause of amelogenesis imperfecta. Am J Hum Genet 2013;92:307-12.

30 Parry DA, Brookes SJ, Logan CV, Poulter JA, El-Sayed W, Al-Bahlani S, Al Harasi S, Sayed J, Raïf EM, Shore RC, Dashash M, Barron M, Morgan JE, Carr IM, Taylor GR, Johnson CA, Aldred MJ, Dixon MJ, Wright JT, Kirkham J, Inglehearn CF, Mighell AJ. Mutations in C4orf26, encoding a peptide with in vitro hydroxyapatite crystal nucleation and growth activity, cause amelogenesis imperfecta. Am J Hum Genet 2012;91:565-71.

31 Huckert M, Stoetzel C, Morkmued S, Laugel-Haushalter V, Geoffroy V, Muller J, Clauss F, Prasad MK, Obry F, Raymond JL, Switala M, Alembik Y, Soskin S, Mathieu E, Hemmerle J, Weickert J-L, Dabovic BB, Rifkin DB, Dheedene A, Boudin E, Caluseriu O, Cholette M-C, Mcleod R, Antequera R, Gelle M-P, Coeuriot J-L, Jacquelin L-F, Bailleul-Forestier I, Maniere M-C, Van Hul W, Bertola D, Dolle P, Verloes A, Mortier G, Dollfus H, Bloch-Zupan A. Mutations in the Latent TGF-beta Binding Protein 3 (LTBP3) gene cause brachyolmia with amelogenesis imperfecta. Hum Mol Genet 2015;24:3038-49.

32 O'Sullivan J, Bitu CC, Daly SB, Urquhart JE, Barron MJ, Bhaskar SS, Martelli-Júnior $H$, dos Santos Neto PE, Mansilla MA, Murray JC, Coletta RD, Black GCM, Dixon MJ. Whole-Exome sequencing identifies FAM20A mutations as a cause of amelogenesis imperfecta and gingival hyperplasia syndrome. Am J Hum Genet 2011;88:616-20.

33 Parry DA, Mighell AJ, El-Sayed W, Shore RC, Jalili IK, Dollfus H, Bloch-Zupan A Carlos R, Carr IM, Downey LM, Blain KM, Mansfield DC, Shahrabi M, Heidari M, 
Aref P, Abbasi M, Michaelides M, Moore AT, Kirkham J, Inglehearn CF. Mutations in CNNM4 cause Jalili syndrome, consisting of autosomal-recessive cone-rod dystrophy and amelogenesis imperfecta. Am J Hum Genet 2009;84:266-73.

34 Schossig A, Wolf NI, Fischer C, Fischer M, Stocker G, Pabinger S, Dander A, Steiner B, TöNz O, Kotzot D, Haberlandt E, Amberger A, Burwinkel B, Wimmer K, Fauth C, Grond-Ginsbach C, Koch MJ, Deichmann A, von Kalle C, Bartram CR, Kohlschütter A, Trajanoski Z, Zschocke J. Mutations in ROGDI Cause Kohlschütter-Tönz Syndrome. Am J Hum Genet 2012;90:701-7.

35 Acevedo AC, Poulter JA, Alves PG, De Lima C, Castro L, Yamaguti P, Paula LM, Parry DA, Logan CV, Smith CEL, Johnson CA, Inglehearn CF, Mighell AJ. Variability of systemic and oro-dental phenotype in two families with non-lethal Raine syndrome with FAM20C mutations. BMC Med Genet 2015;16:8.

36 Wang S, Choi M, Richardson AS, Reid BM, Seymen F, Yildirim M, Tuna E, Gencay K, Simmer JP, Hu JC. STIM1 and SLC24A4 Are Critical for Enamel Maturation. J Dent Res 2014;93(7 Suppl):94S-100S.

37 Mcgrath JA, Gatalica B, Li K, Dunnill MG, McMillan JR, Christiano AM, Eady RA, Uitto J. Compound heterozygosity for a dominant glycine substitution and a recessive internal duplication mutation in the type XVII collagen gene results in junctional epidermolysis bullosa and abnormal dentition. Am J Pathol 1996;148:1787-96.

38 Poulter JA, El-Sayed W, Shore RC, Kirkham J, Inglehearn CF, Mighell AJ. Whole-exome sequencing, without prior linkage, identifies a mutation in LAMB3 as a cause of dominant hypoplastic amelogenesis imperfecta. Eur I Hum Genet 2014;22:132-5

39 Yuen WY, Pasmooij AM, Stellingsma C, Jonkman MF. Enamel defects in carriers of a novel LAMA3 mutation underlying epidermolysis bullosa. Acta Derm Venereol 2012;92:695-6

40 Dong J, Amor D, Aldred MJ, Gu T, Escamilla M, Macdougall M. DLX3 mutation associated with autosomal dominant amelogenesis imperfecta with taurodontism. Am J Med Genet A 2005;133A:138-41.

41 de La Dure-Molla M, Quentric M, Yamaguti PM, Acevedo A-C, Mighell AJ, Vikkula M, Huckert M, Berdal A, Bloch-Zupan A. Pathognomonic oral profile of Enamel Renal Syndrome (ERS) caused by recessive FAM20A mutations. Orphanet I Rare Dis 2014;9:84.

42 Chae JH, Vasta V, Cho A, Lim BC, Zhang Q, Eun SH, Hahn SH. Utility of next generation sequencing in genetic diagnosis of early onset neuromuscular disorders. J Med Genet 2015;52:208-16.

43 DaRe JT, Vasta V, Penn J, Tran NT, Hahn SH. Targeted exome sequencing for mitochondrial disorders reveals high genetic heterogeneity. BMC Med Genet 2013;14:118.

44 Redin C, Gérard B, Lauer J, Herenger Y, Muller J, Quartier A, Masurel-Paulet A, Willems M, Lesca G, El-Chehadeh S, Le Gras S, Vicaire S, Philipps M, Dumas M, Geoffroy V, Feger C, Haumesser N, Alembik Y, Barth M, Bonneau D, Colin E, Dollfus $H$, Doray B, Delrue M-A, Drouin-Garraud V, Flori E, Fradin M, Francannet C, Goldenberg A, Lumbroso S, Mathieu-Dramard M, Martin-Coignard D, Lacombe D, Morin G, Polge A, Sukno S, Thauvin-Robinet C, Thevenon J, Doco-Fenzy M, Genevieve D, Sarda P, Edery P, Isidor B, Jost B, Olivier-Faivre L, Mandel J-L, Piton A. Efficient strategy for the molecular diagnosis of intellectual disability using targeted high-throughput sequencing. J Med Genet 2014;51:724-36.

45 Redin C, Le Gras S, Mhamdi O, Geoffroy V, Stoetzel C, Vincent M-C, Chiurazzi P, Lacombe D, Ouertani I, Petit F, Till M, Verloes A, Jost B, Chaabouni HB, Dollfus H, Mandel J-L, Muller J. Targeted high-throughput sequencing for diagnosis of genetically heterogeneous diseases: efficient mutation detection in Bardet-Biedl and Alström syndromes. J Med Genet 2012;49:502-12.

46 Shearer AE, DeLuca AP, Hildebrand MS, Taylor KR, Gurrola J, Scherer S, Scheetz TE, Smith RJH. Comprehensive genetic testing for hereditary hearing loss using massively parallel sequencing. Proc Natl Acad Sci USA 2010;107:21104-9.

47 Rehm HL. Disease-targeted sequencing: a cornerstone in the clinic. Nat Rev Genet 2013:14:295-300.

48 Eppig JT, Blake JA, Bult CJ, Kadin JA, Richardson JE, Mouse Genome Database G. The Mouse Genome Database (MGD): facilitating mouse as a model for human biology and disease. Nucleic Acids Res 2015;43(Database issue):D726-36.

49 Bradford Y, Conlin T, Dunn N, Fashena D, Frazer K, Howe DG, Knight J, Mani P, Martin R, Moxon SAT, Paddock H, Pich C, Ramachandran S, Ruef BJ, Ruzicka L, Bauer Schaper H, Schaper K, Shao X, Singer A, Sprague J, Sprunger B, Van Slyke C, Westerfield M. ZFIN: enhancements and updates to the Zebrafish Model Organism Database. Nucleic Acids Res 2011;39(Database issue):D822-9.

50 Laugel-Haushalter V, Paschaki M, Thibault-Carpentier C, Dembelé D, Dollé P, Bloch-Zupan A. Molars and incisors: show your microarray IDs. BMC Res Notes 2013:6:113.

51 Li H, Durbin R. Fast and accurate long-read alignment with Burrows-Wheeler transform. Bioinformatics 2010;26:589-95.

52 DePristo MA, Banks E, Poplin R, Garimella KV, Maguire JR, Hartl C, Philippakis AA, Del Angel G, Rivas MA, Hanna M, Mckenna A, Fennell TJ, Kernytsky AM, Sivachenko AY, Cibulskis K, Gabriel SB, Altshuler D, Daly MJ. A framework for variation discovery and genotyping using next-generation DNA sequencing data. Nat Genet 2011;43:491-8.
53 McKenna A, Hanna M, Banks E, Sivachenko A, Cibulskis K, Kernytsky A, Garimella K, Altshuler D, Gabriel S, Daly M, Depristo MA. The Genome Analysis Toolkit: a MapReduce framework for analyzing next-generation DNA sequencing data. Genome Res 2010;20:1297-303.

54 Van Der Auwera GA, Carneiro MO, Hartl C, Poplin R, Del Angel G, Levy-Moonshine A, Jordan T, Shakir K, Roazen D, Thibault J, Banks E, Garimella KV, Altshuler D, Gabriel S, DePristo MA. From FastQ data to high confidence variant calls: the Genome Analysis Toolkit best practices pipeline. Curr Protoc Bioinformatics 2013;11:11 10 1-11 1033.

55 Cingolani P, Platts A, Wang Le L, Coon M, Nguyen T, Wang L, Land SJ, Lu X, Ruden DM. A program for annotating and predicting the effects of single nucleotide polymorphisms, SnpEff: SNPs in the genome of Drosophila melanogaster strain w1118; iso-2; iso-3. Fly 2012;6:80-92.

56 Geoffroy V, Pizot C, Redin C, Piton A, Vasli N, Stoetzel C, Blavier A, Laporte J, Muller J. VaRank: a simple and powerful tool for ranking genetic variants. PeerJ 2015;3:e796.

57 Abecasis GR, Auton A, Brooks LD, DePristo MA, Durbin RM, Handsaker RE, Kang HM, Marth GT, McVean GA, 1000 Genomes Project Consortium. An integrated map of genetic variation from 1,092 human genomes. Nature 2012;491:56-65.

58 Exome Variant Server, NHLBI GO Exome Sequencing Project (ESP), Seattle, WA. http://evs.gs.washington.edu/EVS/ (accessed Feb 2015).

59 Adzhubei IA, Schmidt S, Peshkin L, Ramensky VE, Gerasimova A, Bork P, Kondrashov AS, Sunyaev SR. A method and server for predicting damaging missense mutations. Nat Methods 2010;7:248-9.

60 Kumar P, Henikoff S, Ng PC. Predicting the effects of coding non-synonymous variants on protein function using the SIFT algorithm. Nat Protoc 2009;4:1073-81.

61 Schwarz JM, Cooper DN, Schuelke M, Seelow D. MutationTaster2: mutation prediction for the deep-sequencing age. Nat Methods 2014;11:361-2.

62 Cartegni L, Wang J, Zhu Z, Zhang MQ, Krainer AR. ESEfinder: a web resource to identify exonic splicing enhancers. Nucleic Acids Res 2003;31:3568-71.

63 Desmet FO, Hamroun D, Lalande M, Collod-Beroud G, Claustres M, Beroud C. Human Splicing Finder: an online bioinformatics tool to predict splicing signals. Nucleic Acids Res 2009;37:e67.

64 Fairbrother WG, Yeh RF, Sharp PA, Burge CB. Predictive identification of exonic splicing enhancers in human genes. Science 2002;297:1007-13.

65 Pertea M, Lin X, Salzberg SL. GeneSplicer: a new computational method for splice site prediction. Nucleic Acids Res 2001;29:1185-90.

66 Reese MG, Eeckman FH, Kulp D, Haussler D. Improved splice site detection in Genie. J Comput Biol 1997;4:311-23.

67 Yeo G, Burge CB. Maximum entropy modeling of short sequence motifs with applications to RNA splicing signals. I Comput Biol 2004;11:377-94.

68 Richards CS, Bale S, Bellissimo DB, Das S, Grody WW, Hegde MR, Lyon E, Ward BE. ACMG recommendations for standards for interpretation and reporting of sequence variations: revisions 2007. Genet Med 2008;10:294-300.

69 Kraytsberg Y, Nekhaeva E, Chang C, Ebralidse K, Khrapko K. Analysis of somatic mutations via long-distance single molecule PCR. DNA Amplif 2004:97-110.

70 Ruano G, Kidd KK, Stephens JC. Haplotype of multiple polymorphisms resolved by enzymatic amplification of single DNA molecules. Proc Natl Acad Sci USA 1990:87:6296-300.

71 Pfaffl MW. A new mathematical model for relative quantification in real-time RT-PCR. Nucleic Acids Res 2001;29:e45.

72 Seymen F, Lee KE, Tran Le CG, Yildirim M, Gencay K, Lee ZH, Kim J-W. Exonal deletion of SLC24A4 causes hypomaturation amelogenesis imperfecta. I Dent Res 2014:93:366-70.

73 Darling TN, Mcgrath JA, Yee C, Gatalica B, Hametner R, Bauer JW, Pohla-Gubo G, Christiano AM, Uitto J, Hintner H, Yancey KB. Premature termination codons are present on both alleles of the bullous pemphigoid antigen 2/type XVII collagen gene in five Austrian families with generalized atrophic benign epidermolysis bullosa. J Invest Dermatol 1997;108:463-8.

74 Mcgrath JA, Pulkkinen L, Christiano AM, Leigh IM, Eady RA, Uitto J. Altered laminin 5 expression due to mutations in the gene encoding the beta3 chain (LAMB3) in generalized atrophic benign epidermolysis bullosa. J Invest Dermatol 1995; 104:467-74.

75 Wright JT, Torain M, Long K, Seow K, Crawford P, Aldred MJ, Hart PS, Hart TC. Amelogenesis imperfecta: genotype-phenotype studies in 71 families. Cells Tissues Organs 2011;194:279-83.

76 Lee SK, Hu JC, Bartlett JD, Lee K-E, Lin BP-J, Simmer JP, Kim J-W. Mutational spectrum of FAM83H: the C-terminal portion is required for tooth enamel calcification. Hum Mutat 2008;29:E95-9.

77 van den Boogaard MJ, Créton M, Bronkhorst Y, Van Der Hout A, Hennekam E, Lindhout $D$, Cune M, Ploos Van Amstel HK. Mutations in WNT10A are present in more than half of isolated hypodontia cases. J Med Genet 2012;49:327-31.

78 Bohring A, Stamm T, Spaich C, Haase C, Spree K, Hehr U, Hoffmann M, Ledig S, Sel $S$, Wieacker $P$, Röpke A. WNT10A mutations are a frequent cause of a broad spectrum of ectodermal dysplasias with sex-biased manifestation pattern in heterozygotes. Am J Hum Genet 2009;85:97-105. 
79 Plaisancié J, Bailleul-Forestier I, Gaston V, Vaysse F, Lacombe D, Holder-Espinasse M, Abramowicz M, Coubes C, Plessis G, Faivre L, Demeer B, Vincent-Delorme C, Dollfus $H$, Sigaudy $S$, Guillén-Navarro $E$, Verloes A, Jonveaux $P$, Martin-Coignard D, Colin E, Bieth E, Calvas P, Chassaing N. Mutations in WNT10A are frequently involved in oligodontia associated with minor signs of ectodermal dysplasia. Am J Med Genet A 2013;161:671-8.

80 Xiao S, Yu C, Chou X, Yuan W, Wang Y, Bu L, Fu G, Qian M, Yang J, Shi Y, Hu L, Han B, Wang Z, Huang W, Liu J, Chen Z, Zhao G, Kong X. Dentinogenesis imperfecta 1 with or without progressive hearing loss is associated with distinct mutations in DSPP. Nat Genet 2001;27:201-4.

81 Wang Z, Zhang W, Wang Y, Meng Y, Su L, Shi H, Huang S. Mucopolysaccharidosis IVA mutations in Chinese patients: 16 novel mutations. J Hum Genet 2010:55:534-40.

82 Cho SH, Seymen F, Lee KE, Lee S-K, Kweon Y-S, Kim KJ, Jung S-E, Song SJ, Yildirim M, Bayram M, Tuna EB, Gencay K, Kim J-W. Novel FAM20A mutations in hypoplastic amelogenesis imperfecta. Hum Mutat 2012;33:91-4.

83 Kivirikko S, Mcgrath JA, Pulkkinen L, Uitto J, Christiano AM. Mutational hotspots in the LAMB3 gene in the lethal (Herlitz) type of junctional epidermolysis bullosa. Hum Mol Genet 1996;5:231-7.

84 Ogawa T, Tomatsu S, Fukuda S, Yamagishi A, Rezvi GMM, Sukegawa K, Kondo N, Suzuki Y, Shimozawa N, Orii T. Mucopolysaccharidosis IVA: screening and identification of mutations of the N-acetylgalactosamine-6-sulfate sulfatase gene. Hum Mol Genet 1995;4:341-9.

85 Pasmooij AM, Pas HH, Jansen GH, Lemmink HH, Jonkman MF. Localized and generalized forms of blistering in junctional epidermolysis bullosa due to COL17A1 mutations in the Netherlands. Br J Dermatol 2007;156:861-70.

86 Murrell DF, Pasmooij AM, Pas HH, Marr P, Klingberg S, Pfendner E, Uitto J, Sadowski S, Collins F, Widmer R, Jonkman MF. Retrospective diagnosis of fatal BP180-deficient non-Herlitz junctional epidermolysis bullosa suggested by immunofluorescence (IF) antigen-mapping of parental carriers bearing enamel defects. J Invest Dermatol 2007;127:1772-5.

87 Floeth M, Bruckner-Tuderman L. Digenic junctional epidermolysis bullosa: mutations in COL17A1 and LAMB3 genes. Am J Hum Genet 1999;65:1530-7.

88 Beyeler M, Schild C, Lutz R, Chiquet M, Trueb B. Identification of a fibronectin interaction site in the extracellular matrix protein ameloblastin. Exp Cell Res 2010;316:1202-12.

89 Zhang $X$, Diekwisch TG, Luan X. Structure and function of ameloblastin as an extracellular matrix protein: adhesion, calcium binding, and CD63 interaction in human and mouse. Eur J Oral Sci 2011;119(Suppl 1):270-9.

90 Polok B, Escher P, Ambresin A, Chouery E, Bolay S, Meunier I, Nan F, Hamel C, Munier FL, Thilo B, Mégarbané A, Schorderet DF. Mutations in CNNM4 cause recessive cone-rod dystrophy with amelogenesis imperfecta. Am J Hum Genet 2009;84:259-65.

91 Mendelsohn NJ, Wood T, Olson RA, Temme R, Hale S, Zhang H, Read L, White KK. Spondyloepiphyseal dysplasias and bilateral legg-calvé-perthes disease: diagnostic considerations for mucopolysaccharidoses. JIMD Rep 2013;11:125-32.

92 Gardner DG. The dental manifestations of the Morquio syndrome (mucopolysaccharidosis type IV). A diagnostic aid. Am J Dis Child 1975; 129:1445-8.

93 Levin LS, Jorgenson RJ, Salinas CF. Oral findings in the Morquio syndrome (mucopolysaccharidosis IV). Oral Surg Oral Med Oral Pathol 1975;39:390-5.

94 Rølling I, Clausen N, Nyvad B, Sindet-Pedersen S. Dental findings in three siblings with Morquio's syndrome. Int J Paediatr Dent 1999;9:219-24.
95 Liu F, Chu EY, Watt B, Zhang Y, Gallant NM, Andl T, Yang SH, Lu M-M, Piccolo S, Schmidt-Ullrich R, Taketo MM, Morrisey EE, Atit R, Dlugosz AA, Millar SE. Wnt/ beta-catenin signaling directs multiple stages of tooth morphogenesis. Dev Biol 2008:313:210-24.

96 de Ligt J, Willemsen MH, van Bon BW, Kleefstra T, Yntema HG, Kroes T, Vulto-Van Silfhout AT, Koolen DA, De Vries P, Gilissen C, Del Rosario M, Hoischen A, Scheffer H, De Vries BBA, Brunner HG, Veltman JA, Vissers LELM. Diagnostic exome sequencing in persons with severe intellectual disability. $N$ Engl J Med 2012;367:1921-9.

97 Tucci V, Kleefstra T, Hardy A, Heise I, Maggi S, Willemsen MH, Hilton H, Esapa C, Simon M, Buenavista M-T, Mcguffin LJ, Vizor L, Dodero L, Tsaftaris S, Romero R, Nillesen WN, Vissers LELM, Kempers MJ, Vulto-Van Silfhout AT, Iqbal Z, Orlando M, Maccione A, Lassi G, Farisello P, Contestabile A, Tinarelli F, Nieus T, Raimondi A, Greco B, Cantatore D, Gasparini L, Berdondini L, Bifone A, Gozzi A, Wells S, Nolan PM. Dominant beta-catenin mutations cause intellectual disability with recognizable syndromic features. J Clin Invest 2014;124:1468-82.

98 McKnight DA, Suzanne Hart P, Hart TC, Hartsfield JK, Wilson A, Wright JT, Fisher LW. A comprehensive analysis of normal variation and disease-causing mutations in the human DSPP gene. Hum Mutat 2008;29:1392-404.

99 Gregory-Evans CY, Moosajee M, Hodges MD, Mackay DS, Game L, Vargesson N, Bloch-Zupan A, Ruschendorf F, Santos-Pinto L, Wackens G, Gregory-Evans K. SNP genome scanning localizes oto-dental syndrome to chromosome 11q13 and microdeletions at this locus implicate FGF3 in dental and inner-ear disease and FADD in ocular coloboma. Hum Mol Genet 2007;16:2482-93.

100 Grozeva D, Carss K, Spasic-Boskovic O, Parker MJ, Archer H, Firth HV, Park S-M, Canham N, Holder SE, Wilson M, Hackett A, Field M, Floyd JAB, Hurles M, Raymond FL. De novo loss-of-function mutations in SETD5, encoding a methyltransferase in a 3p25 microdeletion syndrome critical region, cause intellectual disability. Am J Hum Genet 2014;94:618-24.

$101 \mathrm{Ng} \mathrm{SB}$, Bigham AW, Buckingham KJ, Hannibal MC, Mcmillin MJ, Gildersleeve HI, Beck AE, Tabor HK, Cooper GM, Mefford HC, Lee C, Turner EH, Smith JD, Rieder MJ, Yoshiura K, Matsumoto N, Ohta T, Niikawa N, Nickerson DA, Bamshad MJ, Shendure J. Exome sequencing identifies MLL2 mutations as a cause of Kabuki syndrome. Nat Genet 2010;42:790-3.

102 Chan HC, Estrella NM, Milkovich RN, Kim JW, Simmer JP, Hu JC. Target gene analyses of 39 amelogenesis imperfecta kindreds. Eur J Oral Sci 2011;119(Suppl 1):311-23.

103 Gasse B, Karayigit E, Mathieu E, Jung S, Garret A, Huckert M, Morkmued S, Schneider C, Vidal L, Hemmerle J, Sire J-Y, Bloch-Zupan A. Homozygous and compound heterozygous MMP20 mutations in amelogenesis imperfecta. J Dent Res 2013;92:598-603.

104 Wood TC, Harvey K, Beck M, Burin MG, Chien Y-H, Church HJ, D'Almeida V, van Diggelen OP, Fietz M, Giugliani R, Harmatz P, Hawley SM, Hwu W-L, Ketteridge D, Lukacs Z, Miller N, Pasquali M, Schenone A, Thompson JN, Tylee K, Yu C, Hendriksz CJ. Diagnosing mucopolysaccharidosis IVA. J Inherit Metab Dis 2013;36:293-307.

105 Arzoo PS, Klar J, Bergendal B, Norderyd J, Dahl N. WNT10A mutations account for (1/4) of population-based isolated oligodontia and show phenotypic correlations. Am J Med Genet A 2014;164A:353-9.

106 Mostowska A, Biedziak B, Zadurska M, Dunin-Wilczynska I, Lianeri M, Jagodzinski PP. Nucleotide variants of genes encoding components of the Wnt signalling pathway and the risk of non-syndromic tooth agenesis. Clin Genet 2013;84:429-40. 